\title{
PEMBERIAN MAKANAN PENDAMPING ASI (MP-ASI) BERHUBUNGAN DENGAN KEJADIAN STUNTING PADA BALITA
}

\author{
Riska Wandini ${ }^{1}$, Rilyani $^{2}$, Eneng Resti ${ }^{3}$ \\ 1,2,3Program Studi Ilmu Keperawatan Universitas Malahayati \\ *Korespondensi e-mail : enengresti261@gmail.com
}

\section{ABSTRACT SUPPL YING ASI (MP-ASI) COMPLEMENTARY FOOD ASSOCIATED WITH STUNTING EVENTS IN BABIES}

Background: The prevalence of children under five with stunting in Indonesia in 2017 (36.4\%) according to the 2018 Basic Health Research Lampung, which was ranked 24th out of 32 provinces in Indonesia, namely $27.3 \%$ with the highest incidence in Way Kanan (36.07\%) being the lowest are in Metro City (14.75\%). One of the factors causing stunting is the provision of complementary feeding (MP-ASI) which is not fulfilled in terms of time, frequency and type of food given to toddlers.

Purpose: To knowing the relationship between complementary feeding (MP-ASI) and the incidence of stunting in mothers who have the characteristics of children aged 7-24 months at Public Health Services (Puskesmas) Hanura Teluk Pandan Pesawaran Regency 2020.

Methods: This type of quantitative research used a cross sectional design and the population of this study were mothers who had children aged 7-24 months in the Hanura Public Health Center with 41 respondents using total sampling technique. The instrument in this study used a questionnaire sheet and the determination of stunting by calculating the Z-Score $P B / U<-2 S D$, bivariate analysis using the Chi-Square test.

Results: The statistical test of complementary feeding (MP-ASI) Chi-Square obtained $P$-Value $=0.000$ with an Odd Ratio value of 0.083 .

Conclusion: There is a relationship between complementary feeding (MP-ASI) with the incidence of stunting in children under five at the working area of Public Health Services (Puskesmas) Hanura Teluk Pandan District, Pesawaran Regency in 2020.

Suggestions will further improve the community outreach program, especially for mothers who have a toddler to prevent stunting in the future.

Keywords : Stunting, complementary feeding, toddlers

\section{ABSTRAK}

Pendahuluan: Prevalensi balita stunting di Indonesia pada tahun 2018 adalah 30,8\% menurut Riset Dasar Kesehatan tahun 2018 Lampung menjadi peringkat ke-24 dari 32 provinsi di Indonesia yaitu 27,3\% dengan kejadian tertinggi di Way Kanan 36,07\% sedang yang terendah terdapat di Kota Metro 14,75\%. Salah satu faktor penyebab stunting adalah pemberian makanan pendamping ASI (MP-ASI) yang tidak terpenuhi baik dari waktu, frekuensi serta jenis makanan yang diberikan kepada balita.

Tujuan: Untuk mengetahui hubungan pemberian makanan pendamping ASI (MP-ASI) dengan kejadian stunting pada ibu yang memiliki karakteristik balita usia 7-24 bulan di wilayah kerja Puskesmas Hanura Kecamatan Teluk Pandan Kabupaten Pesawaran Tahun 2020.

Metode: Jenis penelitian kuantitatif dengan menggunakan rancangan cross sectional dan populasi dari penelitian ini yaitu ibu yang memiliki balita usia 7-24 bulan di wilayah kerja Puskesmas Hanura dengan jumlah responden 41 orang dengan teknik total sampling. Instrumen dalam penelitian ini dengan menggunakan lembar kuesioner dan penentuan stunting dengan perhitungan Z-Score $\mathrm{PB} / \mathrm{U}<-2 \mathrm{SD}$ analisis bivariat dengan menggunakan uji Chi-Square.

Hasil: Uji statistik pemberian makanan pendamping ASI (MP-ASI) Chi-Square didapat $P$-Value $=0.000$ sehingga $P$-Value $<$ a $(0,000<0,05)$ maka $\mathrm{H} 0$ ditolak dengan nilai Odd Ratio0.083.

Kesimpulan: Terdapat hubungan pemberian makanan pendamping ASI (MP-ASI) dengan kejadian stunting pada balita di wilayah kerja Puskesmas Hanura Kecamatan Teluk Pandan Kabupaten Pesawaran Tahun 2020. Saran agar Puskesmas Hanura Kecamatan Teluk Pandan Kabupaten Pesawaran semakin meningkatkan program penyuluhan kepada masyarakat terutama pada ibu yang memiliki balita untuk mencegah terjadinya stunting dikemudian hari.

Kata kunci : Stunting, MP-ASI, Balita 


\section{JKM (Jurnal Kebidanan Malahayati),Vol 7,No.2.April 2021, ISSN (Print) 2476-8944 ISSN (Online) 2579-762X, Hal 274-278}

\section{PENDAHULUAN}

Stunting merupakan dimana tubuh anak mengalami kegagalan tumbuh akibatnya dapat terjadi kekurangan gizi kronis hingga anak terlalu pendek pada usianya. Prevalensi stunting pada balita menurut World Health Organization (WHO), negara dengan prevalensi tertinggi ketiga regional Asia Tenggara/ South-East Asia Regional (SEAR), prevalensi Indonesia terkait stunting pada balita tahun 2017 yaitu 36,4\% dan pada tahun 2018 yaitu $30,8 \%$ (World Health Organization WHO) dalam Kementerian Kesehatan Republik Indonesia, 2018).

Dampak jangka pendek dari Stunting yaitu meningkatnya kejadian kesakitan dan kematian, perkembangan kognitif, motorik, dan verbal pada anak tidak optimal, dan meningkatnya biaya kesehatan. Sedangkan dampak jangka panjangnya yaitu postur tubuh yang tidak optimal saat dewasa (lebih pendek dibandingkan pada umumnya), meningkatnya risiko obesitas dan penyakit lainnya, menurunnya kesehatan reproduksi, kapasitas belajar dan performa yang kurang optimal saat masa sekolah, dan produktivitas dan kapasitas kerja yang tidak optimal (Kementerian Kesehatan Republik Indonesia dalam Buletin Stunting, 2018)

Faktor penyebab stunting yaitu keluarga dan rumah tangga, pemberian makanan pendamping ASI (MP-ASI) yang tidak adekuat, beberapa masalah dalam pemberian ASI, infeksi dan kelainan endokrin (World Health Organization (WHO) dalam Rahayu, A.,Yulidasari, F., Putri, A. O., \& Anggraini, L., 2018)

Data pravalensi status gizi tinggi badan per umur menurut provinsi berdasarkan hasil survei riset kesehatan dasar 2018, Lampung menjadi peringkat ke-24 dari 32 provinsi di Indonesia dengan kejadian stunting yaitu $27,3 \%$ dan Kabupaten Pesawaran menjadi urutan ketujuh dengan kejadian stunting $27,49 \%$, yaitu pada Puskesmas Hanura dengan jumlah balita 2.013 dan jumlah stuntingnya sebanyak 588 balita (3,45\%) (Dinas Kesehatan Kabupaten Pesawaran, 2019).

World Health Organization (WHO)/ United Nations Children's Fund (UNICEF) menyarankan makan yang diberikan untuk bayi yakni diberikannya secara eksklusif sejak lahir hingga umur 6 bulan yang dahulu diberikan InisiasiMenyusui Dini (IMD)segera setelah lahir, pada usia 6 bulan diberikan Makanan Pendamping ASI (MP-ASI) serta dilanjutkan menyusui sampai berusia 2 tahun (Kementerian Kesehatan dalam Afriyani, R.,Halisa, S., \& Rolina, H., 2016).

Penelitian Sastria, A., Hasnah, H., \& Fadli, F., (2019) dengan judul "Faktor Kejadian Stunting Pada Anak dan Balita" penelitian ini diperoleh jumlah balita dan anak yang diberikan MP-ASI pada usia 6 bulan sebanyak $29(55,8 \%)$ orang dan mengalami kejadian stunting sebanyak $3,8 \%$. Sedangkan balita dan anak yang tidak diberikan MP-ASI sebanyak $23(44,2 \%)$ orang dan mengalami stunting sebanyak $26,9 \%$. Berdasarkan uji chi square pada continuity correction diperoleh hasil $p=0,001 \quad(O R=26,91)$ yang artinya ada hubungan yang signifikan antara faktor pemberian MP-ASI eksklusif dengan kejadian stunting pada anak dan balita.

Berdasarkan hasil prasurvei yang dilakukan pada tanggal 1 Agustus 2020 di wilayah kerja Puskesmas Hanura Kabupaten Pesawaran terhadap 10 balita didapatkan $8(80 \%)$ balita usia 7-24 bulan berada di bawah minus 2 standar deviasi (<-2 SD) oleh karena itu peneliti tertarik melakukan penelitian "Hubungan Pemberian Makanan Pendamping Asi (MP-ASI) dengan Kejadian Stunting Pada Balita Di Wilayah Kerja Puskesmas Hanura Kecamatan Teluk Pandan Kabupaten Pesawaran Tahun 2020" mengingat masih tingginya tingkat stunting di Indonesia dengan tujuan dapat diketahui hubungan pemberian makanan pendamping ASI (MP-ASI) dengan kejadian stunting pada ibu yang memiliki karakteristik balita usia 7-24 bulan di wilayah kerja Puskesmas Hanura Kecamatan Teluk Pandan Kabupaten Pesawaran Tahun 2020. Dan diharapkan masyarakat terutama ibu yang memiliki karakteristik balita usia 7-24 bulan dapat meningkatkan kembali pemberian makanan pendamping ASI (MP-ASI) kepada balitanya secara tepat dan benar untuk mencegah terjadinya stunting.

\section{METODOLOGI PENELITIAN}

Penelitian ini merupakan jenis penelitian kuantitatif menggunakan survei analitik dengan menggunakan pendekatan Cross Sectional dimana pengumpulan data untuk variabel resiko atau sebab (independent variable) maupun variabel akibat (dependent variable) dilakukan dalam waktu yang samam '(Notoatmodjo, S., 2018). Penelitian ini dilaksanakan di wilayah kerja puskesmas Hanura kecamatan Teluk Pandan kabupaten Pesawaran. Populasi dalam penelitian ini adalah seluruh ibu yang memiliki karakteristik balita berusia 7-24 bulan di wilayah kerja puskesmas Hanura dengan berbagai latar belakang. Total ibu yang memiliki balita usia 7-24 bulan di wilayah kerja Puskesmas Hanura Kecamatan Teluk Pandan yaitu berjumlah 4438 orang. Sampel yang digunakan pada penelitian ini adalah 100 orang ibu yang memiliki balita usia 7-24 bulan di wilayah kerja Puskesmas 
Hanura Kecamatan Teluk Pandan Kabupaten Pesawaran Tahun 2020. Teknik sampling yang digunakan pada penelitian ini yaitu sensus atau sampling total dimana seluruh anggota populasi dijadikan sampel semua. Instrumen penelitian yang digunakan yaitu kuesioner yang telah melalui uji validitas dan reabilitas yang telah dilakukan oleh Tanti, S. (2018) yang berjudul "Hubungan Pemberian Makanan Pendamping ASI (MP-ASI) Dini Dengan Status Gizi Dan Kejadian Diare Pada Bayi Usia 0-6 Bulan Di Posyandu Balita Wilayah Kelurahan Banjarejo Kota Madiun"

\section{HASIL DAN PEMBAHASAN}

Tabel 1.

Distribusi Frekuensi Karakteristik Responden Berdasarkan Jenis Kelamin Dan UsiaDi Wilayah Kerja Puskesmas Hanura Kecamatan Teluk Pandan Kabupaten Pesawaran Tahun 2020

\begin{tabular}{lcc}
\hline \multicolumn{1}{c}{ Karakteristik } & N & Persentase (\%) \\
\hline Jenis Kelamin & & \\
Laki-laki & 58 & $58.0 \%$ \\
Perempuan & 42 & $42.0 \%$ \\
Usia & & \\
6-8bulan & 10 & $10.0 \%$ \\
9-1 bulan & 20 & $20.0 \%$ \\
12-24bulan & 70 & $70.0 \%$ \\
\hline \multicolumn{1}{c}{ Total } & 100 & $100 \%$ \\
\hline
\end{tabular}

Distribusi frekuensi berdasarkan tabel 1 menunjukkan bahwa jenis kelamin terbanyak adalah laki-laki dengan jumlah 58 responden $(58.0 \%)$, dan perempuan 42 responden $(42.0 \%)$. Distribusi frekuensi berdasarkan usia menunjukan bahwa responden terbanyak pada usia 12-24 bulan yaitu sebanyak 70 responden $(70.0 \%)$, di usia 9-11 bulan yaitu sebanyak 20 responden $(20.0 \%)$ dan pada usia 6-8 bulan yaitu sebanyak 10 responden (10.0\%).

Analisis Bivariat
Hasil penelitian Larasati, N.N., \& Wahyuningsih, H. P., (2018) menunjukan bahwa balita yang mengalami stunting dan berjenis kelamin laki-laki yaitu sebesar $63,2 \%$. Balita yang tidak mengalami stunting dan berjenis kelamin lakilaki yaitu sebesar 35,5\%. Hasil uji statistik didapatkan $p$-value 0,001 berarti dapat disimpulkan bahwa ada hubungan antara jenis kelamin dengan kejadian stunting. Stunting berpeluang 3,111 kali $(95 \%$ Cl 1,605-6,030) pada balita yang berjenis kelamin laki-laki berpeluang dibanding balita yang berjenis kelamin perempuan.

\section{Analisis Univariat}

Tabel 2.

Distribusi Frekuensi Berdasarkan Pemberian Makanan Pendamping ASI (MP-ASI) Di Wilayah Kerja Puskesmas Hanura Kecamatan Teluk Pandan Kabupaten Pesawaran 2020

\begin{tabular}{ccc}
\hline $\begin{array}{c}\text { Pemberian } \\
\text { MP-ASI }\end{array}$ & Frekuensi & Persentase (\%) \\
\hline Sesuai & 44 & $44.0 \%$ \\
Tidak Sesuai & 56 & $56.0 \%$ \\
\hline Total & 100 & $100 \%$ \\
\hline
\end{tabular}

Tabel 3.

Distribusi Frekuensi Berdasarkan Kejadian Stunting Di Wilayah Kerja Puskesmas Hanura Kecamatan Teluk Pandan Kabupaten Pesawaran 2020

\begin{tabular}{ccc}
\hline $\begin{array}{c}\text { Kejadian } \\
\text { Stunting }\end{array}$ & Frekuensi & $\begin{array}{c}\text { Persentase } \\
(\%)\end{array}$ \\
\hline-3 sampai <-2 & 68 & $68.0 \%$ \\
SD Stunting & & \\
-2 SD sampai 2 & & \\
SD Tidak & 32 & $32.0 \%$ \\
Stunting & & \\
\hline Total & 100 & $100 \%$ \\
\hline
\end{tabular}

Tabel 4.

Hubungan Pemberian Makanan Pendamping ASI (MP-ASI) Dengan Kejadian Stunting Pada Balita Di Wilayah Kerja Puskesmas Hanura Kecamatan Teluk Pandan Kabupaten Pesawaran Tahun 2020

\begin{tabular}{|c|c|c|c|c|c|c|c|c|}
\hline \multirow{3}{*}{$\begin{array}{c}\text { Pemberian } \\
\text { MP-ASI }\end{array}$} & \multicolumn{4}{|c|}{ Kejadian Stunting } & \multirow{2}{*}{\multicolumn{2}{|c|}{ Total }} & \multirow{3}{*}{$P$-Value } & \multirow{3}{*}{ OR } \\
\hline & \multicolumn{2}{|c|}{$\begin{aligned} & -3 \text { sampai } \\
< & -2 \text { SD Stunting }\end{aligned}$} & \multicolumn{2}{|c|}{$\begin{array}{l}\text {-2 SD sampai } 2 \text { SD } \\
\text { Tidak Stunting }\end{array}$} & & & & \\
\hline & $\mathrm{N}$ & $\%$ & $\mathrm{~N}$ & $\%$ & $\mathrm{~N}$ & $\%$ & & \\
\hline Sesuai & 18 & $18.0 \%$ & 26 & $26.0 \%$ & 44 & $44.0 \%$ & & $0.083(0.029$ \\
\hline Tidak Sesuai & 50 & $50.0 \%$ & 6 & $6.0 \%$ & 56 & $56.0 \%$ & 0.000 & $-0.235)$ \\
\hline Total & 68 & $68.0 \%$ & 32 & $32.0 \%$ & 100 & $100.0 \%$ & & \\
\hline
\end{tabular}





\section{PEMBAHASAN}

\section{Analisis Univariat}

Stunting

Dari hasil penelitian didapatkan bahwa yang stunting yaitu sebanyak 68 responden (68.0\%), sedangkan responden yang tidak stunting yaitu 32 responden $(32.0 \%)$

Penelitian ini sejalan dengan penelitian yang dilakukan oleh Sentana, L. F., Hrp, J. R., \& Hasan, Z., (2018) dari hasil pengukuran pada 133 anak, yang mengalami stunting sebanyak 30 anak $(22,6 \%)$ dan 103 anak $(77,4 \%)$ yang tidak mengalami stunting. Hasil penelitian ini lebih tinggi dari kejadian stunting di Kecamatan Sukajadi sebesar $13 \%$. Angka tersebut menunjukkan bahwa kejadian stunting masih menjadi masalah kesehatan pada anak baduta karena usia ini tergolong dalam fase kritis pertumbuhan anak dan mengingat dampak stunting bagi kelangsungan hidup anak.

Hasil penelitian yang diperoleh bahwa di wilayah kerja Puskesmas Hanura Kecamatan Teluk Pandan Kabupaten Pesawaran saat pengukuran tinggi badan pada balita terdapat 68 balita dari 100 responden yang menujukan tinggi badannya tidak sesuai dengan usia dan hanya 32 balita dari 100 responden yang menunjukan tinggi badannya sesuai dengan usia. Ini menunjukan bahwa setengah dari jumlah balita yang ada di wilayah kerja Puskesmas Hanura Kecamatan Teluk Pandan Kabupaten Pesawaran mengalami stunting.

\section{Pemberian Makanan Pendamping ASI (MP-ASI)}

Dari hasil penelitian didapatkan bahwa dari 30 responden pemberian MP-ASI yang tidak sesuai yaitu 56 responden (56.0\%). Sedangkan, responden yang sesuai dalam Pemberian MP-ASI yaitu 44 responden (44.0\%).MP-ASI adalah makanan serta minuman bervariasi yang khusus diberikan kepada bayi. MP-ASI dibagi menjadi dua yaitu yang dibuat sendiri dirumah (MP-ASI keluarga) serta MP-ASI siap saji (pabrikan) (Paramashanti, 2019). Hal ini dikarenakan ASI hanya mampu memenuhi duapertiga kebutuhan bayi pada usia 6-9 bulan, dan pada 9-12 bulan memenuhi setengah dari kebutuhan bayi (Suhartini dalam Datesfordate, A. H., Kundre, R., \& Rottie, J. V., 2017). Tujuannya adalah untuk melengkapi zat gizi yang kurang karena kebutuhan zat gizi yang semakin meningkat sejalan dengan pertambahan usia, mengembangkan kemampuan balita untuk menerima bermacam-macam makanan dengan berbagai bentuk, tekstur dan rasa (Sitompul, E. M. A., 2014).
Penelitian ini sejalan dengan penelitian yang dilakukan oleh Khasanah, D. P., Hadi, H., \& Paramashanti, B. A., (2016) dengan judul "Waktu Pemberian Makanan Pendamping ASI (MP-ASI) Berhubungan dengan Kejadian Stunting Anak Usia 6-23 Bulan Di Kecamatan Sedayu" bahwa diperoleh hasil bahwa ada hubungan bermakna $(p=0.002)$ antara waktu memulai pemberian MP-ASI dengan status gizi anak usia 6-23 bulan berdasarkan panjang badan menurut umur $(\mathrm{PB} / \mathrm{U})(\mathrm{OR}=2,867$, 95\% Cl:1,453-5,656). Anak yang mendapatkan MPASI yang tidak sesuai dengan waktu memulai pemberian MP-ASI memiliki risiko 2,8 kali untuk menjadi stunting ( $z$ score $<-2$ ). Hal ini berarti waktu memulai pemberian MP-ASI berhubungan secara signifikan dengan kejadian stunting.

Hasil analisa peneliti diperoleh pada saat wawancara bahwa kebanyakan ibu memberikan makanan pendamping ASI (MP-ASI) untuk balita mereka lebih awal karena sudah merasa anaknya cukup untuk mendapatkan MP-ASI hal ini terbukti pada saat pengisian kuesioner ibu yang memberikan makanan pendamping ASI sebelum 4 bulan dari 100 responden yaitu sebanyak 54 responden. Hal ini sejalan dengan penelitian yang dilakukan oleh Prihutama, N. Y., Rahmadi, F. A., \& Hardaningsih, G. (2018) diperoleh hasil $(p=0.000)$ dimana responden memberikan makanan pendamping ASI sebanyak (65.4\%). Selain diberikan makanan pendamping ASI (MP-ASI) lebih awal pada 38 responden juga sangat sedikit yang memberikan makanan pendamping ASI (MP-ASI) pada usia 9-12 bulan yaitu dengan porsi $175-250 \mathrm{ml}$ atau satu mangkuk, sedangkan balita sangatlah membutuhkan banyak asupan sesuai usianya karena semakin bertambah usia semakin banyak kebutuhan asupan dan nutrisi yang dibutuhkan. Kemudian pada 46 responden ibu memperkenalkan makanan lembek pada usia 7 bulan dan lebih dari setengahnya tidak memperkenalkan makanan lembek pada usia 7 bulan. Sedangkan pada usia 7 bulanlah balita seharusnya sudah diperkenalkan dengan MP-ASI yaitu dengan mulai memberikan makanan bertekstur lembek. Pada kuesioner pada nomor 10, 11,12 diketahui rata-rata 63 responden yang memberikan variasi pada balita, dari hasil penelitian Nurdin, S. S. I., Katili, D. N. O., \& Ahmad, Z. F. (2019) dengan hasil $p=0.035$ didapatkan bahwa Akibat dari pemberian MPASI yang monoton akan membuat kebutuhan gizi balita tidak terpebuhi. Akibat kekurangan asupan energi akan membuat tubuh menghemat energi sehingga berdampak pada hambatan kenaikan berat badan dan pertumbuhan linier. Loya, R. R. P., \& Nuryanto, N. (2017) Jenis makanan yang dikonsumsi balita dan 


\section{JKM (Jurnal Kebidanan Malahayati),Vol 7,No.2.April 2021, ISSN (Print) 2476-8944 ISSN (Online) 2579-762X, Hal 274-278}

pola makan juga mempengaruhi asupan zat gizi balita.Pola makan terdiri dari pola pemberian ASI, lama waktu pemberian ASI serta makanan pendamping ASI.

\section{Analisis Bivariat}

Hubungan Pemberian Makanan Pendamping ASI (MP-ASI) Dengan Kejadian Stunting Pada Balita Di Wilayah Kerja Puskesmas Hanura Kecamatan Teluk Pandan Kabupaten Pesawaran Tahun 2020

Hasil analisis menggunakan Chi-Square didapat $P$-Value $=0.000$ sehingga $P$-Value $<a$ $(0,000<0,05)$ maka HO ditolak. Jadi dapat disimpulkan terdapat hubungan pemberian makanan pendamping ASI (MP-ASI) dengan kejadian stunting di wilayah kerja Puskesmas Hanura Kecamatan Teluk Pandan Kabupaten Pesawaran Tahun 2020. Dari analisis diperoleh pula nilai Odd Ratio0.083 artinya responden dengan pemberian makanan pendamping ASI (MP-ASI) tidak sesuai mempunyai resiko 0.083 untuk menjadikan balita mengalami stunting.

Sesudah bayi berusia 6 bulan, walaupun ketentuannya masih harus menyusui sampai usia 2 tahun, bayi memerlukan makanan pendamping agar pemenuhan gizi untuk tumbuh dapat terpenuhi. World Health Organization (WHO)/ United Nations Children's Fund (UNICEF) dalam ketentuannya mengharuskan bayi usia 6-23 bulan dapat MP-ASI yang adekuat dengan ketentuan dapat menerima minimal 4 atau lebih dari 7 jenis makanan (serealia/ umbi-umbian, kacang-kacangan, produk olahan susu, telur, sumber protein lainnya, sayur dan buah kaya vitamin A, sayur dan buah lainnya-Minimum Dietary Diversity/MMD). Panduan World Health Organization (WHO) dalam Tim Admin HHBF, (2015) untuk pemberian makan bayi dan anak yaitu waktu pemberian makanan/ umur, frekuensi pemberian makanan, banyaknya pemberianmakanan, jenis pemberian makanan, tekstur makanan, variasi makanan, respon saat pemberian makan, kebersihan makanan.

Stunting (kerdil) adalah kondisi dimana balita memiliki panjang atau tinggi badan yang kurang jika dibandingkan dengan umur. Kondisi ini diukur dengan panjang atau tinggi badan yang lebih dari minus dua standar deviasi median standar pertumbuhan anak dari World Health Organization (WHO). Balita stunting termasuk masalah gizi kronik yang disebabkan oleh banyak faktor seperti kondisi sosial ekonomi, gizi ibu saat hamil, kesakitan pada bayi, dan kurangnya asupan gizi pada bayi. Kekurangan gizi terjadi sejak bayi dalam kandungan dan pada masa awal setelah bayi lahir, tetapi kondisi stunting baru nampak setelah bayi berusia 2 tahun (Kementerian Kesehatan RI, 2018).

Penelitian ini sejalan dengan penelitian yang dilakukan oleh Sastria, A., Hasnah, H., \& Fadli, F., (2019) dengan judul "Faktor Kejadian Stunting Pada Anak dan Balita" penelitian ini diperoleh jumlah balita dan anak yang diberikan MP-ASI pada usia 6 bulan sebanyak $29(55,8 \%)$ orang dan mengalami kejadian stunting sebanyak 3,8\%. Sedangkan balita dan anak yang tidak diberikan MP-ASI sebanyak 23 $(44,2 \%)$ orang dan mengalami stunting sebanyak $26,9 \%$. Berdasarkan uji chi square pada continuity correction diperoleh hasil $p=0,001(\mathrm{OR}=26,91)$ yang artinya ada hubungan yang signifikan antara faktor pemberian MP-ASI eksklusif dengan kejadian stunting pada anak dan balita. Dan sejalan dengan penelitian yang dilakukan oleh Widaryanti, R., (2019) dengan judul "Makanan Pendamping ASI Menurunkan Kejadian Stunting pada Balita Kabupaten Sleman" Hasil analisis bivariate dengan uji chi square didapatkan bahwa responden dengan MP-ASI yang tidak tepat sebagian besar mengalami stunting yaitu $47 \quad \%$ dan responden yang memberikan MP-ASI secara tepat status gizinya normal sebanyak $45 \%$. Hasil analisis menunjukan bahwa terdapat hubungan antara pemberian MPASI terhadap kejadian stunting pada balita dengan $p$ value $<0.05$ yaitu $p$ value $=0.000$, dan hasil $\mathrm{OR}=0.643$ menunjukan hubungan antara praktik pemberian MP-ASI dengan kejadian stunting memiliki keeratan yang kuat, bayi yang mengalami stunting sebagian besar tidak mendapatkan MP-ASI yang tepat. Fitri, L., \& Ernita, E. (2019).dengan $p=0.001$ karena memberikan makanan pendamping ASI secara dini yang berakibat balita mengalami diare, infeksi serta alergi pada sistem pencernaan.. Nugroho, A. 2016 dengan hasil $p=0.008$ alasannya ASI yang tidak keluar, atau tidak cukup untuk balita, melanjutkan susu formula sejak dari Rumah Sakit atau bidan, dan alasan kepraktisan saat ditinggal pergi atau bekerja. Nova, M., \& Afriyanti, O. (2018) dengan hasil $p=0.001$ karena tidak terpenuhinya panduan pemberian makanan pendamping ASI menurut WHO pada balita diwilayah ini. Ulfah, M. (2020) dari salah satu kesimpulannya didapatkan bahwa pemberian makanan pendamping ASI yang baik masih sedikit dibandingkan dengan pemberian MP-ASI yang cukup yaitu sebanyak $22,4 \%$. Balita yang diberikan MP-ASI dini akan 1.6 kali beresiko mengalami stunting dibandingkan anak yang diberikan MP-ASI sesuai usia, Cahniago, S. R. R. (2020) $(p=0.002)$. Penelitian ini sejalan dengan peneliian Virginia, A., Maryanto, S., \& Anugrah, R. M. (2020) dengan hasil adanya hubungan frekuensi pemberian MP ASI ( $p$ value $=0,002 ; O R=4,531$ ), 
tekstur MP-ASI yang diberikan ( $p$ value $=0,015$; $\mathrm{OR}=3,304)$, jumlah pemberian MPASI ( $p$ value $=0,020 ; O R=3,6)$, usia pertama pemberian MP$A S I$ ( $p$ value $=0,002 ; O R=4,583$ ) dengan stunting.

Berdasarkan analisa peneliti yang dilakukan pada balita di wilayah kerja Puskesmas Hanura Kecamatan Teluk Pandan Kabupaten Pesawaran dapat diketahui bahwa besarnya signifikasi adalah $0.000<0.05$. hal ini menjawab hipotesis bahwa tingkat signifikan $<0.05 \mathrm{HO}$ ditolak. Maka hasil tersebut dapat dinyatakan bahwa ada hubungan pemberian makanan pendamping ASI (MP-ASI) dengan kejadian stunting pada balita di wilayah kerja Puskesmas Hanura Kecamatan Teluk Pandan Kabupaten Pesawaran Tahun 2020.

Dari pemberian MP-ASI yang sesuai dari jumlah 44 responden (44.0\%), 18 responden $(18.0 \%)$ mengalami stunting dimana saat peneliti melakukan penelitian didapat hasil ukur tinggi badan ibu kurang atau pendek dan saat dilakukan wawancara didapatkan responden memiliki riwayat infeksi, yaitu diare dan alergi pada susu formula yang diberikan. Hal ini sejalan dengan penelitian yang dilakukan oleh Al-Rahmad, A. H., Miko, A., \& Hadi, A. 2013 dengan hasil $p=0.007$ disebabkan oleh balita yang tidak mendapat pemberian MPASI kurang baik dibandingkan dengan yang mendapat pemberian MP-ASI baik di Kota Banda Aceh. Dan pada pemberian MP-ASI yang tidak sesuai dari jumlah 56 responden (56.0\%), 6 responden $(6.0 \%)$ tidak mengalami stunting dikarenakan faktor genetik bahwa saat dilakukan wawancara ibu responden mengatakan dikeluarga tidak memiliki riwayat stunting atau pendek.

Pada distribusi frekuensi berdasarkan jenis kelamin dan umur menunjukan bahwa dari 100 responden jenis kelamin laki-laki lebih banyak yang mengalami stunting yaitu 58 responden $(58.0 \%)$ dibandingkan dengan jenis kelamin perempuan yaitu sebanyak 42 responden. Hal ini menunjukan jenis kelamin laki-laki lebih berpeluang mengalami stunting karena pertumbuhan balita berjenis kelamin laki-laki lebih cepat dibandingkan dengan jenis kelamin perempuan serta asupan yang diperlukan juga lebih banyak. Jikalau pemenuhan nutrisi tidak terpenuhi maka akan menghambat masa pertumbuhan balita tersebut terutama yang berpeluang mengalami stunting. Kemudian pada distribusi frekuensi usia yang mengalami stunting lebih banyak yaitu pada usia 12-24 bulan karena stunting adalah kekurangan gizi yang terjadi sejak bayi dalam kandungan dan pada masa awal setelah bayi lahir, tetapi kondisi stunting baru nampak setelah balita berusia 2 tahun. Hal ini sesuai dengan hasil penelitian Larasati, N.N., \&
Wahyuningsih, H. P., (2018) bahwa balita yang mengalami stunting berjenis kelamin laki-laki yaitu sebesar $63,2 \%$. Balita yang tidak mengalami stunting dan berjenis kelamin laki-laki yaitu sebesar $35,5 \%$. Hasil uji statistik didapatkan $p$-value 0,001 berarti dapat disimpulkan bahwa ada hubungan antara jenis kelamin dengan kejadian stunting. Stunting berpeluang 3,111 kali $(95 \%$ Cl 1,605$6,030)$ pada balita yang berjenis kelamin laki-laki berpeluang dibanding balita yang berjenis kelamin perempuan.

Didapat hasil Odd Ratio sebesar 0.083 dengan data 26 responden $(26.0 \%)$ tidak mengalami stunting, peneliti menyimpulkan bahwa responden mempunyai resiko mengalami stunting sebesar 0.083 diwilayah kerja Puskesmas Hanura Kecamatan Teluk Pandan Kabupaten Pesawaran Tahun 2020. Penyebab terjadinya hubungan pemberian makanan pendamping ASI (MP-ASI) dengan kejadian stunting yaitu terlalu dininya pemberian makanan pendamping ASI (MP-ASI), frekuensi pemberian makanan pendamping ASI (MP-ASI) juga tidak terjadwal, serta variasi makanan pendamping ASI (MP-ASI) tidak lebih dari dua hanya terdiri dari karbohidrat dan protein saja dalam satu menu yang diberikan kepada balita.

Adapun kemungkinan faktor lain yang menjadikan stunting pada penelitian ini yaitu tidak diterapkannya pemberian ASI esklusif dan pemberhentian dini konsumsi ASI hal ini mungkin juga karena rendahnya kesadaran ibu akan pentingnya memberikan ASI pada balitanya dipengaruhi oleh pengetahuan tentang kesehatan dan sosio-kultural, serta terbatasnya petugas kesehatan dalam memberikan penyuluhan.

\section{SIMPULAN}

Dari hasil penelitian dengan judul "Hubungan Pemberian Makanan Pendamping ASI (MP-ASI) Dengan Kejadian Stunting Pada Balita Di Wilayah Kerja Puskesmas Hanura Kecamatan Teluk Pandan Kabupaten Pesawaran Tahun 2020" maka ditarik kesimpulan yaitu: Terdapat Hubungan Pemberian Makanan Pendamping ASI (MP-ASI) Dengan Kejadian Stunting Di Wilayah Kerja Puskesmas Hanura Kecamatan Teluk Pandan Kabupaten Pesawaran Tahun 2020 dengan $P$-Value $=0.000$ dan Odd Ratio 0.083 yang artinya responden dengan pemberian makanan pendamping ASI (MPASI) tidak sesuai mempunyai risiko 0.083 untuk menjadikan balita mengalami stunting.

\section{SARAN}

Diharapkan dapat dipergunakan sebagai bahan masukan dalam membuat kebijakan upaya 


\section{JKM (Jurnal Kebidanan Malahayati),Vol 7,No.2.April 2021, \\ ISSN (Print) 2476-8944 ISSN (Online) 2579-762X, Hal 274-278}

peningkatan status gizi balita dengan pemberian promosi kesehatan terkait pemberian makanan pendamping ASI, pemberian ASI esklusif dan diare serta alergi pada balita kepada ibu yang memiliki balita untuk mencegah terjadinya stunting dan diharapkan juga dapat digunakan sebagai pemberitahuan kepada bidan untuk waspada jika ada ibu balita dengan tinggi badan pendek, balita tidak ASI eksklusif, balita dengan berat lahir rendah karena risiko besar mengalami stunting.

\section{DAFTAR PUSTAKA}

Afriyani, R., Halisa, S., \& Rolina, H. (2016). Faktorfaktor yang berhubungan dengan pemberian MP-ASI pada bayi usia 0-6 bulan di BPM Nurtila Palembang. Jurnal Kesehatan.

Al-Rahmad, A. H., Miko, A., \& Hadi, A. (2013). Kajian stunting pada anak balita ditinjau dari pemberian ASI eksklusif, MP-ASI, status imunisasi dan karakteristik keluarga di Kota Banda Aceh.J Kesehatan IImiah Nasuwakes, 6(2), 169-184.

Angkat, A. H. (2018). Penyakit Infeksi dan Praktek Pemberian MP-ASI Terhadap Kejadian Stunting Pada Anak Usia 12-36 Bulan di Kecamatan Simpang Kiri Kota Subulussalam. Jurnal Dunia Gizi, 1(1), 5258.

Cahniago, S. R. R. (2020). Hubungan Riwayat Pemberian Asi Eksklusif dan Mp-Asi Dini dengan Kejadian Stunting pada Batita di Wilayah Kerja Puskesmas Kecamatan Gunungsitoli Utara.

Datesfordate, A. H., Kundre, R., \& Rottie, J. V.(2017).Hubungan Pemberian Makanan Pendamping Air Susu Ibu (MP-ASI) Dengan Status Gizi Bayi Pada Usia 6-12 Bulan Di Wilayah Kerja Puskesmas Bahu Manado. Jurnal Keperawatan.

Fitri, L., \& Ernita, E. (2019). Hubungan Pemberian Asi Eksklusif dan Mp-asi Dini dengan Kejadian Stunting pada Balita. Al-Insyirah Midwifery: Jurnal Ilmu Kebidanan (Journal of Midwifery Sciences), 8(1), 19-24.

Kementerian Kesehatan Republik Indonesia. (2018). Buletin Stunting. Jakarta: Kementerian Kesehatan Republik Indonesia

Kementerian Kesehatan. (2018). Buku Saku Pemantauan Status Gizi Tahun 2017. Kementrian Kesehatan

Khasanah, D. P., Hadi, H., \& Paramashanti, B. A. (2016). Waktu pemberian makanan pendamping ASI (MP-ASI) berhubungan dengan kejadian stunting anak usia 6-23 bulan di Kecamatan Sedayu. Jurnal Gizi dan
Dietetik Indonesia (Indonesian Journal of Nutrition and Dietetics).

Larasati, N. N., \& Wahyuningsih, H. P., (2018). Faktor-faktor Yang Berhubungan Dengan Kejadian Stunting Pada Balita Usia 25-59 Bulan Di Posyandu Wilayah Puskesmas Wonosari II Tahun 2017. (Doctoral dessertation, Poltekkes Kemenkes Yogyakarta)

Loya, R. R. P., \& Nuryanto, N. (2017). Pola Asuh Pemberian Makan pada Balita Stunting Usia 6-12 bulan di Kabupaten Sumba Tengah Nusa Tenggara Timur (Doctoral dissertation, Diponegoro University).

Nova, M., \& Afriyanti, O. (2018). Hubungan berat badan, asi eksklusif, mp-asi dan asupan Energi dengan stunting pada balita usia 2459 bulan Di puskesmas lubuk buaya. JURNAL KESEHATAN PERINTIS (Perintis's Health Journal), 5(1), 39-45.

Nugroho, A. (2016). Determinan growth failure (stunting) pada anak umur $1 \mathrm{~s} / \mathrm{d} 3$ tahun (studi di Kecamatan Tanjungkarang Barat Kota Bandar Lampung). Jurnal Kesehatan, 7(3), 470-479.

Nurastrini, V. R., \& Kartini, A. (2014). Jenis MP-ASI, Frekuensi Dan Waktu Pertama Kali Pemberian MP-ASI Sebagai Faktor Risiko Kejadian Gizi Lebih Pada Bayi Usia 6-12 Bulan Di Kota Magelang (Doctoral dissertation, Diponegoro University

Nurdin, S. S. I., Katili, D. N. O., \& Ahmad, Z. F. (2019). Faktor ibu, pola asuh anak, dan MPASI terhadap kejadian stunting di kabupaten Gorontalo. Jurnal Riset Kebidanan Indonesia, 3(2), 74-81.

Nurkomala, S., Nuryanto, N., \& Panunggal, B. (2018). Praktik Pemberian MPASI (Makanan Pendamping Air Susu Ibu) pada Anak Stunting dan Tidak Stunting Usia 6-24 Bulan (Doctoral dissertation, Diponegoro University).

Notoatmodjo, S. (2018). Metodologi penelitian kesehatan. Jakarta:Rineka Cipta

Prihutama, N. Y., Rahmadi, F. A., \& Hardaningsih, G. (2018). Pemberian Makanan Pendamping ASI Dini Sebagai Faktor Risiko Kejadian Stunting pada Anak Usia 2-3 Tahun. DIPONEGORO MEDICAL JOURNAL (JURNAL KEDOKTERAN DIPONEGORO), 7(2), 1419-1430.

Rahayu, A, Yulidasari, F., Putri, A.O., \& Anggraini, L.(2018). Study Guide-Stunting dan Upaya Pencegahannya Bagi mahasiswa Kesehatan Masyarakat. Yogyakarta: CV Mine. 
Sastria, A., Hasnah, H., \& Fadli, F. (2019). Faktor Kejadian Stunting Pada Anak Dan Balita. Jurnal IImiah Keperawatan.

Sentana, L. F., Hrp, J. R., \& Hasan, Z. (2018). Faktor-faktor Yang Berhubungan Dengan Kejadian Stunting Pada Anak Usia 12-24 Bulan Di Kelurahan Kampung Tengah Kecamatan Sukajadi Pekanbaru. Jurnal Ibu dan Anak, 6 (1), 01-09.

Sitompul, E. M. A. (2014). Buku pintar MPASI: bayi 6 bulan sampai dengan 1 tahun. Jakarta: Lembar Langit Indonesia.

Siyoto, S., \& Sodik, M. A. (2015). Dasar metodologi penelitian.Yogyakarta: Literasi Media Publishing.

Sjarif, D. R., Yuliarti, K., Lestari, E. D., Sidiartha, I. G. L., Nasar, S. S., \& Mexitalia, M. (2015). Rekomendasi praktik pemberian makan berbasis bukti pada bayi dan balita di Indonesia untuk mencegah malnutrisi. Jakarta: Ikatan Dokter Anak Indonesia.

Sudaryanto, G. (2014). MPASI super lengkap. Jakarta: Penebar PLUS+.

Tanti, S. (2018). Hubungan Pemberian Makanan Pendamping ASI (MP-ASI) Dini Dengan Status Gizi Dan Kejadian Diare Pada Bayi
Usia 0-6 Bulan Di Posyandu Balita Wilayah Kelurahan Banjarejo Kota Madiun (Doctoral dissertation, STIKES BHAKTI HUSADA MULIA.

Tim Admin HHBF. (2015). Mini Ensiklopedia MPASI Sehat Serunya MP-ASI Homemade Ala $H H B F$. Jakarta: PandaMedia.

Ulfah, M. (2020). Hubungan Antara Pola Pemberian MP-ASI dengan Kejadian Stunting Anak Usia 6-23 Bulan di Kelurahan Karyamulya Kecamatan Kesambi Kota Cirebon. JURNAL CAHAYA MANDALIKA (JCM) e-ISSN 27214796, 1(2), 34-40.

Virginia, A., Maryanto, S., \& Anugrah, R. M. (2020). the Correlation Between Complementary Feeding and First Complementary Feeding Time With Stunting in Children of 6-24 Months in Leyangan Village, East Ungaran, Semarang Regency. Jgk, 12(27), 89-98.

Widaryanti, R. (2019). Makanan Pendamping ASI Menurunkan Kejadian Stunting pada Balita Kabupaten Sleman. Jurnal IImiah Kesehatan Ar-Rum Salatiga.

Yuliana, W., ST, S., Keb, M., \& Hakim, B. N. (2019). Darurat Stunting dengan Melibatkan Keluarga.Sulawesi Selatan: Yayasan Ahmar Cendekia Indonesia. 